\title{
MENGURAI BATASAN AURAT WANITA DALAM KELUARGA PERSPEKTIF HUKUM ISLAM
}

\author{
Ipandang \\ Institut Agama Islam Negeri Kendari \\ Email: ipandangiainkendari@gmail.com
}

\begin{abstract}
This paper aims to parse the boundaries of women's genitals in the family from Islamic law, but what is used as a framework for this analysis is M. Quraish Shihab's thoughts. In the Islamic Shari'at, it is obligatory for Muslim men and women to wear clothes that cover their genitals and are polite. The scholars agreed on the obligation to cover the genitals, however, it is different about the limits of the genitals of Muslim women. At this time, male lust arises regardless of clothes, it could be that Muslim women who wear syar'i clothes can be targeted. If Muslim women have closed their genitals, men have to lower their gaze. This paper is devoted to discussing the limits of aurat Muslim women in the family and the public as well as discussions regarding it. From the analysis that has been carried out, Muslim women in the family do not need a veil or veil with a nonmahram, it is only specific to Ummul Mu'minin. Whereas in the public sphere it is recommended to wear the headscarf for philosophical, security, and economic reasons. From the Quraish, there are three limitations to the hijab, namely, philosophical, security, and economic and that is following maqashid shari'ah.
\end{abstract}

Keywords: Limitation of Aurat, Muslim Woman, Family Law

\begin{abstract}
Abstrak
Tulisan ini bertujuan untuk mengurai batasan aurat wanita dalam keluarga dari sudut pandang hukum Islam, namun yang digunakan sebagai kerangka analisis tersebut adalah pemikiran M. Quraish Shihab. Dalam Syari'at Islam mewajibkan ummat muslim laki-laki dan perempuan memakai pakaian yang menutup aurat dan sopan. Ulama sepakat akan wajibnya menutup aurat namun, berbeda tentang batasan aurat wanita muslimah. Saat ini timbulnya birahi pria tidak memandang pakaian, bisa jadi muslimah yang berpakaian syar'i dapat menjadi sasaran. Jika wanita muslimah sudah menutup aurat, maka tugas bagi pria untuk menundukkan pandangan. Tulisan ini dikhususkan untuk membahas batasan aurat wanita muslimah di dalam keluarga dan publik serta pembahasan yang berkenaan dengannya. Dari analisis yang telah di laksanakan, wanita muslimah di dalam keluarga tidak perlu adanya tabir ataupun jilbab dengan non mahram, itu hanya dikhususkan pada Ummul Mu'minin. Sedangkan pada ranah public dianjurkan memakai jilbab dengan alasan filosofis, keamanan, dan ekonomi. Dari sudut pandang Quraish bahwa batasan berhijab itu ada tiga yaitu, filosofis, keamanan, dan ekonomi dan itu sudah sesuai dengan maqashid syari'ah.
\end{abstract}

\section{Kata Kunci: Batasan Aurat, Wanita Muslimah, Hukum Keluarga}




\section{A. Pendahuluan}

Aurat muslimah menjadi bahasan yang fenomenal, karena dalam menentukan batasannya menuai perbedaan antar ulama. Perbedaan tersebut sesuai kondisi wanita, jika selain suami atau mahramnya, maka harus ditutup menyadari bahwa ada hal-hal yang dapat menimbulkan rangsangan bagi pria dan wanita, baik melalui bagian-bagian tertentu dari tubuh maupun dalam bentuk gerak dan dan ucapan. Sesuatu yang rawan itulah yang dinamai aurat. Kewajiban menghindari hal-hal rawan itulah yang melahirkan pembatasan aurat wanita dan pria. Ia juga lah yang melahirkan tuntunan untuk membatasi pandangan pria dan wanita, serta larangan untuk berbicara atau melakukan gerak-gerik yang dapat membuat kerawanan tersebut (Shihab, 2018:56).

Menutup aurat wanita biasa memakai jilbab atau hijab. Kata hijab dan jilbab memiliki pengertian yang nyaris sama. Keduanya sering disebut oleh para ulama untuk menunjukkan pakaian yang wajib dikenakan muslimah di depan lelaki non mahram atau bila keluar rumah. Jilbab merupakan sesuatu yang wajib dikenakan oleh seorang wanita muslimah ketika ia terjun dan bergaul di kehidupan umum (Alawiyah, 2014: 34). Kewajiban ini telah jelas diungkap oleh firman Allah SWT: Artinya: Hai Nabi, Katakanlah kepada isteri-isterimu, anak-anak perempuanmu dan isteri-isteri orang mukmin: "Hendaklah mereka mengulurkan jilbabnya ke seluruh tubuh mereka". yang demikian itu supaya mereka lebih mudah untuk dikenal, karena itu mereka tidak di ganggu. dan Allah adalah Maha Pengampun lagi Maha Penyayang (Depag RI, 1991:234.)

Sebelum turunnya ayat ini, cara berpakaian wanita merdeka atau budak, yang baik-baik atau yang kurang sopan hampir dapat dikatakan sama. Karena itu lelaki usil sering kali mengganggu wanita-wanita khususnya yang mereka ketahui atau duga sebagai hamba sahaya, untuk menghindarkan gangguan tersebut, serta menampakkan kehormatan wanita muslimah maka turunlah ayat tersebut. Thabathaba'i memahami kata jilbab dalam arti pakaian yang menutupi seluruh badan atau kerudung yang menutupi kepala dan wajah wanita. Ibn 'Asyur memahami kata jilbab dalam arti pakaian yang lebih kecil dari jubah tetapi lebih besar dari kerudung atau penutup wajah (Shihab, 2002:319).

Ayat di atas tidak memerintahkan wanita muslimah memakai jilbab, karena agaknya ketika itu sebagian mereka telah memakainya, hanya saja cara 
memakainya belum mendukung apa yang dikehandaki ayat di atas. Kesan ini diperoleh dari redaksi ayat di atas yang menyatakan jilbab mereka dan yang diperintahkan adalah "hendaklah mereka mengulurkannya". Ini berati mereka telah memakai jilbab tetapi belum lagi mengulurkannya. Nah, terhadap mereka yang telah memakai jilbab, tentu lebih-lebih lagi yang belum memakainya, Allah berfirman "hendaklah mereka mengulurkan jilbabnya". Upaya manusia pertama berpakaian rapi, menutup aurat, juga mengisyaratkan bahwa berpakaian rapi sebagaimana dikehendaki agama dapat memberi rasa tenang dalam jiwa pemakainya. Ketenangan batin merupakan salah satu dampak yang dikehendaki oleh agama (2002:320).

Muhammad Quraish Shihab ialah seorang cendekiawan muslim dalam ilmu al-Qur'an. Beliau lahir di Rappang (Sulawesi Selatan) dan berasal dari keturunan Arab yang terpelajar. Dalam hal penafsiran, ia cenderung menekankan pentingnya penggunaan metode tafsir maudu'i (tematik), yaitu penafsiran dengan cara menghimpun sejumlah ayat al-Qur'an yang tersebar dalam berbagai surah yang membahas masalah yang sama, kemudian menjelaskan pengertian menyeluruh dari ayat-ayat tersebut dan selanjutnya menarik kesimpulan sebagai jawaban terhadap masalah yang menjadi pokok bahasan. Menurutnya, penafsiran terhadap al-Qur'an tidak akan pernah berakhir. Dari masa ke masa selalu saja muncul penafsiran baru sejalan dengan perkembangan ilmu dan tuntutan kemajuan (Rony, 2019:4).

Hijab yang belakangan menjadi tren sesungguhnya merupakan perintah Allah kepada kaum muslimah yang sudah ada sejak zaman dahulu. Dalam berhijab, seorang muslimah boleh menampakkan wajah dan telapak kakinya, sementara yang lainnya harus ditutupi baik menggunakan pakaian, jilbab atau kerudung karena masuk dalam aurat. Dalam perkembangannya saat ini, hijab kemudian menjadi komoditas ekonomi sehingga masuk dalam mode yang jenis, model, dan motifnya. Akibatnya, hijab menjadi tren masa kini seiring dengan perkembangan dunia fashion yang staylish Tidaklah mengherankan jika saat ini terjadi peningkatan pemakaian kerudung yang cukup fantastif di negeri ini. Ada juga alasan lain mengenai keengganan dalam berhijab. Yaitu, misalnya "hatiku 
masih belum mantap untuk berhijab. Jika hatiku sudah mantap, aku akan segera berhijab". Memang benar, hijab adalah kemantapan hati seseorang.

\section{B. Landasan Teori}

\section{Dalil tentang Aurat Wanita Muslimah}

Artinya: Katakanlah kepada wanita-wanita mukminah "Hendaklah mereka menahan pandangan mereka, dan memelihara kemaluan mereka dan janganlah mereka menampakkan hiasan mereka kecuali yang tampak darinya dan hendaklah mereka menutupkan kerudung mereka ke dada mereka dan janganlah mereka menampakkan perhiasan mereka, kecuali kepada suami mereka, atau ayah mereka, atau ayah suami mereka, atau putra-putra mereka, atau putra-putra suami mereka, atau saudara-saudara laki-laki mereka, atau putra-putra saudara laki-laki mereka, atau putra-putra saudara perempuan mereka, atau wanitawanita mereka, atau budak-budak yang mereka miliki, atau pelayanpelayan laki-laki yang tidak mempunyai keinginan, atau anak-anak yang belum mengerti tentang aurat-aurat wanita, dan janganlah mereka menghentakkan kaki mereka agar diketahui perhiasan yang mereka sembunyikan dan bertaubatlah kamu sekalian kepada Allah, hai orang-orang mukmin supaya kamu beruntung.

Ayat ini menyatakan: Katakanlah kepada wanita-wanita mukminah: "Hendaklah mereka menahan pandangan mereka, dan memelihara kemaluan mereka sebagaimana perintah kaum pria mukmin untuk menahannya, diriwayatkan pula dari Jarir bin Abdullah Al-Bajali, ia berkata, "Aku pernah bertanya kepada Rasulullah SAW tentang pandangan tiba-tiba, kemudian ia menyuruhku agar memalingkan pandangan ku yang berikutnya (Shihab, 2002:326)

Dengan hal itu janganlah mereka menampakkan hiasan yakni bagian tubuh mereka yang dapat merangsang lelaki kecuali yang biasa nampak darinya atau kecuali yang terlihat tanpa maksud untuk ditampak-tampakkan, seperti wajah dan telapak tangan. Selanjutnya karena salah satu hiasan pokok wanita adalah dadanya maka ayat ini melanjutkan dan hendaklah mereka menutupkan kain kerudung mereka ke dada mereka, dan perintahan juga wahai Nabi bahwa janganlah menampakkan perhiasan yakni keindahan tubuh mereka, kandungan penggalan ayat ini berpesan agar dada ditutup dengan penutup kepala. Apakah ini berarti kepala (rambut) juga harus ditutup? Jawabannya, "Ya". Demikian pendapat yang logis, apalagi jika disadari bahwa rambut adalah mahkota wanita. Bahwa ayat ini 
tidak menyebut secara tegas perlunya rambut ditutup. Memang ada pendapat yang menyatakan bahwa firman Allah illa ma zhahara minha adalah disamping wajah dan kedua telapak tangan, juga kaki dan rambut (Ibn 'Asyur dalam Shihab, 2002:328).

Mempertlihatkan aurat kepada suami mereka karena memang salah satu tujuan perkawinan adalah menikmati hiasan itu, atau ayah mereka, karena ayah sedemikian cinta kepada anak-anaknya sehingga tidak mungkin timbul berahi kepada mereka bahkan mereka selalu menjaga kehormatan anak-anaknya atau ayah suami mereka karena kasih sayangnya kepada anaknya menghalangi mereka melakukan yang tidak senonoh kepada menantu-menantunya. Atau putra-putra mereka karena anak tidak memiliki berahi terhadap ibunya, atau putra-putra suami mereka yakni anak tiri mereka, karena mereka bagaikan anak apalagi rasa takutnya kepada ayah mereka menghalangi mereka usil. Atau saudara-saudara laki-laki mereka, atau putra-putra saudara perempuan mereka karena mereka itu bagaikan anak kandung sendiri, atau wanita-wanita mereka yakni wanita-wanita yang beragama Islam. Karena mereka wanita dan keislamannya menghalangi mereka menceritakan rahasia tubuh wanita yang dilihatnya kepada orang lain berbeda dengan wanita non muslim yang boleh jadi mengungkap rahasia keindahan tubuh mereka adapun aurat wanita terhadap wanita non muslim adalah yang tidak tampak ketika melakukan pekerjaan rumah sehari-hari, seperti kepala dan rambutnya, wajah dan leher, kedua tangan hingga kedua lengannnya, dan kedua kaki hingga kedua lututnya selain itu adalah aurat (Baharun, 2012:149)

Di atas telah dikemukakan bahwa zinah adalah sesuatu yang menjadikan sesuatu yang lain indah yakni hiasan. Sementara ulama membaginya dalam dua macam. Ada yang bersifat khilqiyyah (fisik melekat pada diri seseorang) dan juga yang bersifat muktasabah (dapat diupayakan). Menurut Ibn 'Asyur yang bersifat fisik melekat adalah wajah, telapak tangan, dan setengah dari kedua lengan. Sedang yang diupayakan adalah pakaian yang indah, perhiasan, celak mata, dan pacar. Pakar hukum dan tafsir Ibn al 'Arabi berpendapat bahwa hiasan khilqiyyah adalah sebagian besar jasad perempuan, khususnya wajah, kedua pergelangan tanga, kedua siku sampai bahu, payudara, kedua betis dan rambut. Sedang hiasan 
yang diupayakan adalah hiasan yang lumrah dipakai wanita seperti, perhiasan, pakaian indah, celak, pacar, siwak, dan sebagainya (Shihab, 2002:330).

Ulama yg lain berbeda pendapat, yaitu Abu Al-A'la Al-Maududi menurutnya perempuan muslimah boleh menampakkan perhiasannya (tidak berjilbab) kepada perempuan-perempuan lain meskipun non mslimah. Adapun perempuan fasik yang tidak lagi memiliki rasa malu, yaitu perempuan yang tidak dapat dijadikan pegangan akhlak dan adat kebiasannya, maka perempuan muslimah wajib berhijab terhadapnya meskipun si perempuan fasik itu seorang muslimah. Sebab, bersahabat dengannya tidak berbeda dengan bersahabat dengan laki-laki, dari sudut perangainya yang berbahaya. Atau budak-budak yang mereka miliki, menurut Imam Ahmad, Abu Hanifah, dan salah satu pendapat Imam Syafi'i menyatakan, hamba laki-laki terhadap tuan putrinya sebagaimana laki-laki lain.

Pemahaman mereka yang seperti itu didasarkan pada atsar yang diriwayatkan dari jalur Sa'id Bin Mussayib. Ia berkata, "janganlah kalian salah duga terhadap ayat an-Nur itu, karena sesungguhnya yang dimaksud hamba-hamba itu adalah hamba-hamba perempuan, bukan budak laki-laki atau pelayan-pelayan laki-laki yang tidak mempunyai keinginan yakni berahi terhadap wanita, asalkan laki-laki itu dungu, yang tidak mengerti tentang perempuan dan tidak bersyahwat terhadapnya, entah itu karena kelemahan fisik atau psikis, atau karena kefakiran dan kemiskinan sehingga membuat mereka tidak bergairah terhadap perempuan jika melihatnya. Atau anak-anak yang belum dewasa karena belum mengerti tentang aurat-aurat wanita sehingga belum memahami tentang seks (Shihab, 2002:327).

Anak kecil yang belum tamyiz, maka pengertian haram baginya lemah (al Ghazali, 2009:467). Barangkali pendapat inilah yang benar, yaitu anak-anak yang masih belia, jiwanya belum merasakan adanya perbedaan jenis sehingga tidak mempunyai perhatian khusus terhadap tubuh perempuan dan gerak-geriknya. Ini tidak lain hanya bagi anak-anak di bawah umur sepuluh tahun. Adapun anak-anak yang sudah hampir baligh, mereka mulai mempunyai perasaan adanya perbedaan jenis meskipun umurnya belum mencapai usia baligh, maka seyogyanya perempuan berhijab. Menajaga pandangan mata merupakan bagian terpenting dalam syariat. Wanita yang berjilabab, berarti menutup jalan kaum pria non 
mahram dari pandangan haram. Maka sebaliknya, wanita yang berjilbab juga menjaga pandangan matanya dari yang haram. Kala seorang muslimah tidak mampu menjaga hati dari maksiat, ia pasti akan menjadi bencana bagi lawan jenisnya (Alawiyah, 2014:92)

\section{Pandangan Ulama Empat Madzhab Batasan Aurat Wanita}

Para ulama berbeda pendapat dalam menentukan batasan aurat wanita muslimah yang akan dijelaskan berikut ini:

1. Madzhab Hanafi: Menurut Madzhab Hanafi aurat wanita dengan non mahram adalah seluruh tubuhnya, kecuali wajah, bagian telapak tangan dan bagian luar telapak kaki sampai mata kaki di dalam shalat atau di luarnya. Menurut madzhab ini, wanita yang shalat dalam keadaan telapak tangannya terlihat, maka hukumnya boleh sebagaimana hukumnya boleh kedua telapak kaki bagian luar hingga mata kaki. Namun, apabila disentuh oleh yang bukan mahram atau dilihat dangan pandangan hawa nafsu maka menjadi aurat yang harus ditutupi (Aizid, 2018:200). Selain itu, menurut madzhab hanafi bahwa remaja putri yang belum baligh dilarang membuka wajahnya di hadapan lelaki bukan karena wajah itu aurat, akan tetapi dikhawatirkan menimbulkan fitnah. Madzhab ini juga berpendapat bahwa lantunan suara wanita (bukan berbicara seperti biasa) juga termasuk dalam kategori aurat (Ardiansyah, 2014:264).

2. Madzhab Maliki Bahwa aurat wanita di dalam dan di luar shalat adalah seluruh tubuhnya kecuali wajah dan telapak tangan serta wajib ditutup jika ketika dikhawatirkan terjadinya fitnah. Lalu dalam madzhab ini aurat wanita diklasifikasikan menjadi dua: aurat berat (mughalladhoh) seluruh badannya kecuali dada, rambut, kepala, leher, ujung tangan dan kaki. Sedangkan aurat ringan (mukhaffafah) adalah seluruh tubuhnya kecuali wajah dan telapak tangan. Apabila terbuka bagian dari aurat mughalladhoh dalam shalat padahal ia mampu untuk menutupnya, batal shalatnya dan wajib mengulangnya. Sedangkan apabila aurat mukhaffafah terbuka, tidak batal shalatnya sekalipun membukanya makruh dan haram melihatnya. Adapun aurat wanita di luar shalat dihadapan pria yang bukan mahram adalah seluruh tubuhnya kecuali wajah dan telapak tangan. Dihadapan mahramnya 
seluruh tubuhnya selain wajah, rambut, kepala, leher, ujung tangan dan kaki. Adapun ketika bersama wanita baik mahramnya maupun tidak maka batasan auratnya adalah antara pusat dan lutut (Ardiansyah, 2014:265).

3. Madzhab Syafi'i, Pendapat madzhab Syafi'i tentang batas aurat wanita di dalam shalat yaitu seluruh tubuh kecuali wajah dan kedua telapak tangan. Apabila bagian dari aurat ini terbuka padahal ia mampu untuk menutpnya maka batal shalatnya. Namun, apabila terbuka karena angin atau lupa maka segera ia menutupnya dan tidak batal shalatnya. Adapun di luat shalat maka aurat wanita ketika dihadapan pria bukan mahramnya seluruh tubuhnya. Sedangkan dihadapan wanita lain baik muslimah atau kafir adalah seluruh tubuhnya kecuali bagian tertentu yang terbuka ketika melaksanakan pekerjaan rumah tangga. Adapun aurat wanita ketika ia bersama dengan wanita muslimah dan pria mahramnya adalah antara pusat dan lutut (Dhimyathi, 1994:134).

4. Madzhab Hambali, Terdapat dua riwayat dari Imam Ahmad bin Hanbal, salah satu riwayat menyatakan bahwa aurat wanita baligh seluruh tubuhnya termasuk kuku jari tangan dan wajah. Namun, pendapat yang kuat adalah bahwa aurat wanita di dalam dan di luar shalat adalah seluruh tubuhnya kecuali wajah dan telapak tangan. Sedangkan ketika ia bersama wanita baik mahramnya maupun tidak maka batas auratnya adalah antara pusat dan lutut. Dalam hal ini pendapat hanabilah lebih cenderung kepada madzhab malikiyah (Ardiansyah, 214:266).

Dari paparan di atas, dapat disimpulkan bahwa batasan aurat wanita adalah seluruh tubuhnya kecuali wajah dan telapak tangannya. Oleh karena itu, wajib bagi wanita muslimah merdeka dan baligh untuk menutup auratnya baik di dalam maupun di luar shalat. Selain itu, bagi wanita muslimah hendaklah menjauhi segala bentuk fitnah. Wahbah az-Zuhaily menukilkan ijma' ulama yang menyatakan bahwa wanita muslimah wajib menutup auratnya di dalam dan di luar shalat. Beliau menegaskan, haram membuka sebagaian atau semua aurat kecuali untuk keperluan tertentu seperti mandi, buang hajat, bersuci, dan pemeriksaan dokter (kehamilan atau penyakit). 


\section{Penggunaan Hijab dalam pandangan M. Quraish Shihab}

\section{Hijab dalam sudut pandang kebudayaan}

Pakaian adalah produk budaya sekaligus tuntunan agama dan moral. Dari sini lahir apa yang dinamai pakaian tradisional, daerah, dan nasional, juga pakaian resmi untuk perayaan tertentu, dan pakaian tertentu untuk profesi tertentu, serta pakaian untuk beribadah. Namun, perlu dicatat bahwa sebagian dari tuntunan agaman pun lahir dari budaya masyarakat, karena agama sangat mempertimbangkan kondisi masyarakat sehingga menjadikan adat istiadat, yang tidak bertentangan dengan nilai-nilainya, sebagai salah satu pertimbangan hukum.

Memakai pakaian tertutup bukanlah monopoli masyrakat Arab, dan bukan pula berasal dari budaya mereka, bahkan menurut ulama dan filosof besar Iran kontemporer, Murthadha Muthahari, pakaian penutup (seluruh badan wanita) telah dikenal di kalangan bangsa-bangsa kuno dan lebih melekat pada orang-orang Sassan Iran, dibandingkan dengan di tempat-tempat lain Dalam konteks pakaian, Syahrur menjelaskan bahwa, pakaian tertutup yang kini dinamai hijab (jilbab) bukanlah kewajiban agama melainkan satu bentuk pakaian yang dituntut oleh kehidupan bermasyarakat dan lingkungan serta dapat berubah dengan perubahan masyarakat. Di sisi yang sama tentang tidak wajibnya wanita memakai jilbab, menurut Sa'id al-Asymawi ayat-ayat yang ditunjuk sebagai dalil kewajiban memakai hijab atau jilbab tidaklah mengandung ketatapan hukum yang qath'i tentang keharusan wanita mukminah untuk memakai pakaian tertentu secara mutlak dan sepanjang masa (Shihab, 2002:37).

Adapun pada masa sekarang ketika perbudakan sudah tiada, dan pada konteks masyarakat tertentu kehormatan atau ketidakhormatan tidak disimbolkan dengan pakaian jilbab, maka jika demikian, yang penting dalam konteks pakaian wanita adalah memakai pakaian yang terhormat, sesuai dengan perkembangan budaya positif masyarakat terhormat, dan yang mengantar mereka tidak diganggu atau mengganggu dengan pakainnya itu. Di sisi lain, penampakan setengah betis telah menjadi kebiasaan umum dan tidak lagi menimbulkan rangsangan bagi masyarakat umum, dan juga tidak mengurangi kehormatan seorang wanita. Sehingga berpakaian nasional dengan penampakan rambut serta setengah betis bagi wanita dapat dibenarkan (Tohari, 2011:6). 
Perlu diketahui bahwa wanita Indonesia secara kultural berbeda dengan wanita Arab. Wanita Arab pada umumnya, terutama pada zaman Nabi, tidak disibukkan oleh pekerjaan-pekerjaan yang berat, karena semua pekerjaan seperti itu dilakukan oleh laki-laki atau budak mereka. Wanita Indonesia sejak dahulu berdampingan dengan kaum laki-laki bekerja sama mengurus kehidupannya. Sejak dahulu wanita Indonesia bekerja di kebun, sawah, pantai, pabrik dan sebagainya. Dalam suasana demikian itu, aurat wanita tidak dapat tertutupi secara normal, yakni ketika wanita petani bekerja di sawah tergenam air dan lumpur, memikul peralatan dan hasil pertanian serta mengolah hasil laut. Dalam fikih, wanita tersebut memperoleh keringanan dalam soal aurat dengan alasan untuk meringankan pekerjaan yang ditangani sehari-hari (Sudirman, 2017:327).

Di sisi lain, Islam sangat menghargai keluarga. Keruntuhan keluarga menyebabkan runtuhnya masyarakat dan Negara, begitu juga sebalinya. Adapun ketika wanita keluar rumah dilarang memakai pakaian terbuka yakni tanpa kerudung, tetapi kalau wanita di dalam rumah, hal tersebut dibolehkan, walau ada selain mahram yang melihatnya (Shihab, 2018:108).

\section{Hijab Dalam Sudut Pandang Ketakwaan}

Pakaian tertutup muncul di pentas bumi ini jauh sebelum datangnya Islam. Di India dan Iran lebih keras tuntutannya daripaada yang diajarkan Islam,tulis Muthahari. Pakar lain menambahkan bahwa orang-orang Arab meniru orang Persia, dan juga meniru masyarakat Byzantium (Romawi) yang memingit wanita di rumah, dan ini bersumber dari masyarakat Yunani kuno Muthahhari menambahkan pokok persoalan jilbab sebenarnya bukan apakah sebaiknya wanita berjilbab dalam pergaulannya dengan masyarakat, melainkan apakah laki-laki bebas mencari kelezatan dan kepuasan dalam memandang wanita. (Katni, 2018:41). Quraish Shihab menyebut beberapa alas an yang diduga mengakibatkan adanya keharusan bagi wanita untuk memakai pakaian tertutup.

1. Alasan pertama antara lain adalah alasan filosofis yang berpusat pada kecenderungan kearah kerahiban dan perjuangan melawan kenikmatan demi melawan nafsu manusiawi. Muthahari menduga bahwa sumber utama pemikiran ini adalah India. Wanita adalah bentuk tertinggi kesenangan 
sehingga jika lelaki diberi kesempatan berkumpul bebas dengan wanita maka perhatian dan kegiatan lelaki hanya akan tertuju kepada wanita. Akibatnya, kegiatan positif akan sangat berkurang dan masyarakat tidak akan mengalami kemajuan. Dari sini manusia harus berjuang menguasai dirinya guna menolak kesenangan-kesenangan seksual.

Jilbab disyariatkan dalam Islam untuk menanamkan suatu tradisi yang menyeluruh dan penting untuk mencabut akar-akar kerusakan akhlak yang buruk atau dalam bahasa umum disebut sebagai rusaknya moral. Syariat jilbab atau pakaian esensinya adalah untuk menutup pergaulan bebas. Karena pergaulan bebas akan menimbulkan perzinaan, pelecehan, hancurnya harapan hidup, wibawa diri dan keluarga. Para kaum beriman hendaknya tidak mengikuti orang-orang barat yang menuhankan nafsu mengutamakan kelezatan dan kesenangan dengan yang bukan mahramnya. Mereka saling menikmati dan menganggap pernikahan adalah belenggu keterikatan dan penjara bagi mereka Hasyim Asy'ari juga berpendapat bahwa aurat wanita merdeka adalah seluruh badannya kecuali wajah dan telapak tangannya, tapi hukum tersebut berubah menjadi haram, artinya wajib menutup wajah dan telapak tangan ketika seorang pria melihatnya dapat menimbulkan fitnah, artinya pandangan yang mengandung birahi dan menariknya untuk mengajak maksiat (Asy'ary, 1995:66).

Alasan kedua adalah alasan keamanan, Pada masa lalu, yang kuat sering kali merampas tidak saja harta benda orang lain, tetapi juga isterinya, apalagi jika sang istri cantik. Konon Nabi Ibrahim as. terpaksa menyatakan bahwa yang bersama dia adalah saudara perempuannya, padahal dia adalah istri beliau, karena khawatir istrinya dirampas oleh penguasa masanya. Alasan ini pun bukan menjadi pertimbangan Islam ketika menetapkan batasbatas yang boleh dilihat dari sosok perempuan. Salah satu buktinya adalah ketika perintah mengenakan jilbab turun, Islam di Madinah sudah mulai amat mapan. Islam mengajarkan bahwa pakaian adalah penutup aurat, bukan sekedar perhiasan. Islam mewajibkan setiap wanita dan pria untuk menutupi anggota tubuhnya yang menarik perhatian lawan jenisnya (Baso, 2005:188). 
2. Alasan ketiga adalah alasan ekonomi. Mereka meduga bahwa lelaki mengeksploitasi wanita dengan menugaskan mereka melakukan aneka aktivitas untuk kepentingan lelaki. Pandangan ini jelas bukan alasan Islam menetapkan pakaian tertentu atau menganjurkan pembagian kerja yakni pria di luar rumah dan wanita di dalam rumah. Dalam pandangan Islam, wanita sebagai istri berhak memperoleh segala kebutuhannya dari suaminya. Dia boleh menolak setiap tugas yang dibebankan suaminya guna melakukan pekerjaan dalam konteks kehidupan ekonomi keluarga. Dan, jika para istri melakukan aktivitas ekonomi di dalam atau di luar rumah, maka mereka berhak sepenuhnya atas hasil usahanya. Suami tidak boleh mengambil sedikit pun, kecuali atas kerelaannya.

Di sisi lain, seorang suami yang baik akan membantu istrinya dalam tugas-tugas rumah tangga. Nabi saw. Melakukan hal tersebut, sampaisampai beliau membersihkan rumah, memerah susu kambing untuk minum beliau, bahkan menjahit pakaian beliau yang sobek. Sejak zaman Nabi pun ada perempuan-perempuan yang keluar rumah untuk bekerja guna mendukung ekonomi keluarga. Bantuan istri, kalau tidak dapat dalam bentuk bekerja mencari nafkah, maka paling tidak menyiapkan suasana kondusif yang menjadikan suami merasa. teduh, hilang penatnya, dan bangkit semangatnya, sehingga dapat bekerja lebih giat dan tekun, lau merasa dihargai hasil usahanya walau hanya sedikit (Shihab, 2015:187).

Kebutuhan hidup dari hari ke hari tambah banyak dan mahal, inilah yang juga menuntut banyak istri untuk bekerja, guna menambah penghasilan suami. Jika tidak bekerja, maka rumah tangga akan susah, anak-anak juga akan kekurangan. Jika ia tidak bekerja maka aka nada mudharat yang lebih besar. Karena itu ulama kontmporer mengemukakan pendapat mereka, perempuan boleh bekerja selama pekerjaan itu membutuhkannya atau dia dan keluarganya yang membutuhkannya, dan selama dia dapat menjaga diri untuk tidak mengganggu atau terganggu, merangsang atau dirangsang. (Hefni, 2014:209). Sungguh amat disesalkan bahwa di Negara yang mayoritas muslim ada pengusaha yang berani memaksa pegawainya berpakaian minim (Zahro, 2017:105) 


\section{Metode Penelitian}

Jenis ini adalah penelitian kepustakaan (library research). Dalam konteks penelitian, kajian kepustakaan adalah upaya mencari dan menghimpun bahan dari sumber buku, hasil penelitian dan sebagainya yang terkait dengan persoalan penelitian yang akan dilakukan, baik dalam bentuk penjelasan aspek fokus penelitian, maupun untuk mempertegas posisi penelitian yang akan dilakukan (standing position) (Ibrahim, 2015:35).

Sedangkan pendekatan penelitian yang digunakan dalam penelitian ini adalah pendekatan naratif riset yakni yaitu suatu metode yang mengumpulkan cerita (argumen) dari beberapa tokoh yang membahas aurat wanita muslimah dan mengkaji hukum Islam dalam kedudukannya sebagai aturan, baik yang terdapat dalam nash maupun yang telah menjadi produk pemikiran. Ciri dari naratif riset adalah mengumpulkan cerita (peneliti dan partisipan), menuturkan pengalaman individu, data berasal dari pengumpulan dokumen, sumber data kualitatif, data disusun berdasar kronologi masa lalu, sekarang dan masa depan. Tipe dari naratis riset adalah studi biografi: studi naratif tentang kehidupan seseorang, autoetnografi: pemikiran seseorang sebagai ide, sejarah kehidupan secara utuh, sejarah tutur: narasi dapat di padu dengan kerangka penafsiran.

Sumber data dapat diklasifikasikan menjadi dua, yaitu data primer dan data sekunder. 1) Data Primer yaitu data yang diperoleh langsung dari sumber utama, yaitu: Jilbab Pakaian Wanita Muslimah karangan M. Quraish Shihab. 2) Data Sekunder yaitu mencakup buku-buku yang membahas aurat wanita muslimah, artikel-artikel, dan buku hasil penelitian yang bersifat laporan yang sesuai dengan pembahasan penelitian.

Teknik pengumpulan data merupakan langkah yang paling strategis dalam penelitian, karena tujuan utama dalam penelitian adalah mendapatkan data. Tanpa mengetahui teknik pengumpulan data, maka peneliti tidak akan mendapatkan data yang memenuhi standar data yang ditetapkan (Sugiono, 2009:244). Dalam penelitian menggunakan metode pengumpulan data dokumentasi dengan menelusuri buku-buku atau karya ilmiyah lainnya yang berkaitan dengan topik kajian. Diawali dengan buku-buku karangan M. Quraish Shihab, seperti tafsir almisbah vol. 9 dan 11, jilbab pakaian wanita muslimah: pandangan ulama masa 
lalu dan cendekiawan kontemporer, dan buku-buku lain yang membahas aurat wanita muslimah.

Analisis data menggunakan pandangan Miles dan Huberman (2014:16) dalam menganalisis data kualitatif tersebut, yaitu tetap menggunakan kata-kata yang biasanya disusun ke dalam teks kemudian akan sedikit di naratifkan oleh penulis. Analisis ini menurut Miles dan Huberman memiliki tiga alur kegiatan yang terjadi secara bersamaan yaitu: reduksi data, penyajian data dan penarikan kesimpulan atau verivikasi. Reduksi data diartikan sebagai proses pemilihan, pemusatan perhatian pada penyederhanaan, pengabstrakan, dan transformasi data kasar yang muncul dari catatan-catatan tertulis.

\section{Hasil}

\section{Kontribusi M. Quraish Shihab Terhadap Batasan Aurat Wanita Muslim}

Pemakaian jilbab dalam arti busana yang menutupi seluruh tubuh wanita atau yang dikecualikan wajah dan telapak tangan, dalam kurun waktu duapuluh tahun terakhir ini semakin banyak peminatnya. Tidak hanya kalangan muslimah yang sudah berkeluarga, muslimah yang sudah baligh pun banyak yang berjilbab. Perintah hijab di dalam keluarga pertama kali diperintahkan kepada istri-istri Nabi, sesuai dengan al-Qur'an surah al-Ahzab ayat 53:

Artinya: Hai orang-orang yang beriman, janganlah kamu memasuki rumahrumah Nabi kecuali bila kamu diizinkan untuk Makan dengan tidak menunggu-nunggu waktu masak (makanannya) tetapi jika kamu diundang Maka masuklah dan bila kamu selesai makan, keluarlah kamu tanpa asyik memperpanjang percakapan. Sesungguhnya yang demikian itu akan mengganggu Nabi lalu Nabi malu kepadamu (untuk menyuruh kamu keluar), dan Allah tidak malu (menerangkan) yang benar. apabila kamu meminta sesuatu (keperluan) kepada mereka (isteri- isteri Nabi), Maka mintalah dari belakang tabir. cara yang demikian itu lebih suci bagi hatimu dan hati mereka. dan tidak boleh kamu menyakiti (hati) Rasulullah dan tidak (pula) mengawini isteri- isterinya selama-lamanya sesudah ia wafat. Sesungguhnya perbuatan itu adalah Amat besar (dosanya) di sisi Allah.

Jika merujuk pada surah al-Ahzab ayat 53 tersebut, para ulama berpendapat bahwa seluruh tubuh wanita adalah aurat walau wajah dan telapak tangannya, mencakup semua wanita muslimah bukan hanya istri-istri Nabi dengan beberapa alasan. Pertama, kenyataannya pada masa Nabi, tidak hanya istri-istri Nabi yang 
memakai hijab dalam arti menutupi seluruh badannya, tetapi juga waita muslimah lainnya. Kedua, adanya larangan memasuki rumah Nabi tanpa izin. Bukan berarti larangan itu khusus buat rumah Nabi, tapi juga untuk rumah semua orang. Ketiga, firman Allah yang artinya "itu lebih suci bagi hatimu dan hati mereka." Kesucian hati tidak hanya dituntut dari istr-istri Nabi, tetapi semua kaum muslim. Kita diperintahkan mengikuti dan meneladani beliau kecuali dalam hal-hal yang dikhususkan Allah terhadap Nabi bukan ummatnya.

Dengan demikian, surah al-Ahzab ayat 53 tersebut menjadi dasar sebagian ulama, bahwa aurat wanita muslimah ketika berada di dalam rumah adalah seluruh tubuhnya, termasuk wajah dan telapak tangan. Bahkan lebih dari itu, sosoknya pun harus tertutup dengan tabir ketika ada yang bukan mahram hendak berbicara dengannya, dan kalau di luar rumah harus ada semacam kubah yang menghalangi pandangan terhadapnya. Yang perlu diketahui bahwa pemahaman tersebut adalah pemahaman dan logika masing-masing ulama. Kalau kita menoleh ke pendapat-pendapat lain, akan kita temukan perbedan pendapat ulama' dalam mengartikan hijab. Dalam konteks ini sebagian ulama' memahami kata hijab bukan dalam arti pakaian tetapi tabir atau tirai.

Fenomena berjilbab dikalangan masyarakat muslimah yang semakin marak, salah satu faktornya adalah mengentalnya kesadaran beragama. Namun, ada wanita yang berjilbab tetapi gerak-geriknya tidak sejalan dengan tuntunan agama dan budaya masyarakat Islam. Mereka tanpa malu berdansa sambil memegang tangan bahkan pinggul pria yang bukan mahramnya. Itu dilakukan di hadapan umum bahkan terlihat dalam tayangan televisi. Di sini, mereka mengenakan jilbab bukan sebagai tuntunan agama, melainkan sebagai salah satu mode berpakaian. Selain itu pakaian juga memberi dampak psikologis bagi pemakainya, semisal pergi ke pesta dengan mengenakan pakaian sehari-hari, pasti pemakainya akan merasa rikuh. Namun, akan merasa percaya diri apabila mengenakan pakaian istimewa. Dalam konteks hubungan pria dan wanita, Muthahari menjelaskan wanita biasanya selalu ingin mendapat perhatian pria. Biasanya wanita merupakan pemburu hati pria, sedangkan pria pemburu tubuh wanita (Shihab, 2018:55).

Begitulah nafsu manusia kecuali yang mendapat rahmat Allah. Nafsu diibaratkan dengan eksim, semakin digaruk akan terasa nikmat, tetapi jika 
diteruskan akan berakibat infeksi. Begitu juga dengan hasrat seksual pria lebih mudah terangsang, bahkan kadang-kadang tanpa rangsangan. Seperti sedikit senyum atau betis terungkap sedikit, bisa jadi menimbulkan perasaan bermacammacam. Di sini Islam tidak memerintahkan membunuh nafsu, melainkan mengendalikannya. Cara untuk menghadapi kekhawatiran itu bukan dengan menutup-nutupi kemudahan ajaran, sehingga Islam tampil sangat kaku dan keras. Cara menghadapinya dengan menanamkan nilai-nilai Ilahi, membentuk kepribadian muslim dan muslimah melalui dakwah yang sejuk dan mengemasnya dalam bentuk yang menarik. Turunnya tuntunan al-Qur'an menyangkut berpakaian jilbab adalah salah satu bukti bahwa ketika itu ada juga orang-orang nakal di tengah masyarakat Nabi. Saat ini aneka kebejatan telah merajalela, tapi hendaknya tidak berburuk sangka.

\section{E. Pembahasan}

\section{Kontribusi M. Quraish Shihab Terhadap Batasan Aurat Wanita Muslim}

Kontribusi atau manfaat penelitian mengenai batasan aurat wanita muslimah atas pendapat ulama Indonesia yaitu Quraish Shihab sangat pro dan kontra. Pendapat Quraish yang mengatakan bahwa yang terpenting dari pakaian wanita muslimah adalah pakaian terhormat, sebatas leher, setengah tangan dan betis. Saat ini sangat lumrah wanita muslimah berpakaian seperti itu, karena tuntutan pekerjaan, budaya lingkungan setempat, kenyamanan dan merasa tidak akan digoda oleh laki-laki usil. Bukan hanya wanita yang tidak sepenuhnya menutup aurat, wanita yang menutup seluruh tubuhnya pun bisa membuat birahi pria.

Pakaian terhormat ini bisa diterapkan di Indonesia, karena berbagai tuntutan dan perbedaan budaya. Selama pakaian tersebut tidak mengganggu atau di ganggu orang lain. Tapi tidak jika kita berada di daerah yang aturan Perdanya mewajibkan jilbab meskipun terhadap wanita non muslimah. Berbeda jika kita berada di Bali misalnya, tidaklah pantas apabila berpakaian bikini. Meskipun kita tidak diganggu tapi pakaian tersebut tidaklah sesuai dengan budaya Indonesia, agama, kehormatan, dan termasuk tabarruj Maqashid Syari'ah yang dirumuskan asySybithi ada lima, yaitu: hifdz din (menjaga agama), hifdz nafs (memelihara jiwa), hifdz 'aql (memelihara akal), hifdz nasab (memelihara keturunan), dan hifdz maal 
(memelihara harta). Maqashid Syari'ah adalah konsep untuk mengetahui nilainilai yang tersirat dan tersurat dalam al-Qur'an dan hadits, yang ditetapkan oleh Allah untuk manusia. Tujuan hukum tersebut untuk kemaslahatan atau kebaikan dan kesejahteraan umat manusia di dunia dan akhirat. Cara untuk mencapai kebaikan tersebut dengan memenuhi kebutuhan primer (dharuriat), dan menyempurnakan kebutuhan sekunder (hajiyah) dan tersier (tahsiniat) (Zaeinuddin, 2018:7)

Primer (dharuriat) ini sesuatu yang harus ada untuk mewujudkan kebaikan dunia dan akhirat, jika tidak ada maka akan terjadi kehancuran dalam dunia ataupun akhirat. Dlaruriyah ini mencakup hifdz din, nafs, 'aqal, nasl, dan maal. Sekunder (hajiyah) adalah sesuatu yang diperlukan keberadaannya untuk kemudahan dalam hidup, namun tidak sampai pada kehancuran dunia dan akhir misalnya diperbolehkannya menjamak dan mengqasar shalat bagi musafir. Tersier (tahsiniat) adalah sesuatu yang patut ada karena tuntutan kesopanan. Jika tidak, maka dinilai tidak pantas. Contohnya menutup aurat di luar dan di dalam ibadah dan menjauhi makanan dan minuman yang najis.

Pertama, memelihara agama. Syariat Islam mengajarkan untuk menciptakan sikap hormat dan menjaga keyakinan yang ada, agar dalam masyarakat yang berada dalam naungan syari'ah Islami dapat hidup berdampingan secara damai, saling menjaga, dan menghormati. Dalam hal ini Allah mewajibkan keimanan dan rukun-rukun Islam seperti, syahadat, shalat, zakat, puasa, dan haji, serta peribadatan lain yang meneguhkan hati. Untuk melindungi agama diwajibkan perang atau jihad terhadap orang yang menghina agama, memberi hukuman bagi orang yang keluar dari agama (Masruroh, 2018:80).

Kedua, menjaga jiwa. Islam mengajarkan untuk memelihara jiwa, menghormati keamanan, keselamatan diri manusia, dan menjadi tetap dihormatinya kemuliaan martabat manusia sebagai anugerah dari Allah. Untuk menjaga jiwa, manusia diperintahkan untuk makan, minum, berpakaian, dan bertempat tinggal. Ditetapkan hukum qisas, diyat, dan kafarat bagi orang yang melakukan kejahatan terhadap jiwa.

Ketiga, memelihara akal. Akal adalah dimensi paling penting dalam kehidupan manusia, keberadaannya menjadi pembeda utama dengan makhluk lain 
serta menjadi alasan mengapa Allah menetapkan kewajiban-kewajiban kepada manusia. Akal juga menentukan baik buruknya perilaku hidup dan peradaban, oleh karena itu apapun yang dapat merugikan fungsi pemikiran, baik dalam bentuk fisik maupun non fisik dicegah oleh syari'at islam. Untuk memelihara akal manusia dilarang melakukan hal-hal yang merusak akal seperti meminum minuman yang memabukkan dan memberikan hukuman bagi orang yang melanggar aturan tersebut. (Masruroh, 2018:81).

Keempat, melindungi keturunan. Islam mengajarkan untuk memelihara dan menghormati sistem keluarga (keturunan), sehingga masing-masing orang mempunyai garis keturunan yang jelas. Seorang yang menikah pasti menginginkan untuk mendapatkan keturunan. Untuk memelihara keturunan, manusia diperintahkan untuk menikah dengan ketentuan dan syari'at agama, dan menghukum orang yang melanggarnya seperti melakukan perzinaan dan menuduh zina (qazaf).

Kelima, memelihara harta. Untuk memelihara harta, syari'at islam memerintahkan manusia untuk mencari harta atau rizki yang halal lagi baik dengan bekerja atau berdagang. Jika mereka melanggar, maka diterapkan hukuman had bagi pencuri atau larangan melakukan penipuan, memakan harta orang lain secara batil serta diharamkannya riba (Masruroh, 2018:82).

Menutup aurat selain adanya menjaga agama ketika shalat, juga berfungsi sebagai hifdz maal, yaitu menjaga harta. Seperti wanita karir yang dituntut memakai jilbab. Namun, ketika di tempat yang budayanya baik tidak masalah walau tanpa jilbab. Dengan mencari rezeki yang halal, akhlak baik, berpakaian sopan, dan terhormat meskipun tanpa jilbab. Kelonggaran tentang batasan aurat muslimah ini sesuai dengan budaya Indonesia, kecuali sebagian kecil daerah. Karena istri dan anak sebagian ulama Indonesia pun tidak sepenuhnya menutup aurat. Jadi, berpakaian itu sesuai dengan kebutuhan dan kenyamanan masingmasing individu, selama tidak ada pengaruh negatif terhadap wanita muslimah maka tidak masalah.

Bagi wanita muslimah yang berprofesi pekerja kasar seperti, pertanian, pekebunan, maupun di pantai misalnya. Disituasi seperti ini disulitkan bagi mereka jika harus menutup seluruh tubuhnya, kesulitan ini mengakibatkan mereka 
lambat dalam bekerja. Hubungan dengan maqasid syari'ahnya yaitu hifdz maal, karena ada kewajiban untuk memenuhi kehidupan keluarga, selama pekerjaan halal dan tidak dikhawatirkan adanya birahi. Sedangakan bagi wanita karir yang paling terhormat adalah menutup seluruh tubuh minimal yang terlihat wajah dan telapak tangan seperti pendapat mayoritas ulama. Jika tidak, yang terpenting memakai pakaian terhormat dan itu sesuai dengan hifdz nafs atau memelihara jiwa, keamanan, dan keselamatan.

Memakai pakaian terhormat, sesuai budaya terhormat masyarakat, pendapat ini mungkin dapat diterima bagi muslimah awam yang berada di lingkungan sehat dan tidak dikhawatirkan adanya birahi bagi non mahram. Selama pakaian itu tidak ketat sehingga memperlihatkan lekukan tubuhnya, tidak transparan, tidak mengundang perhatian pria, tidak ada unsur tabarruj seperti memakai make up berlebihan, berjalan dengan berlenggak-lenggok, berbicara tidak sopan, dan bukan pakaian yang menyerupai pakaian pria. Dalam hal berpakaian wanita muslimah bebas menentukannya, sesuai kemantapan hati, kenyamanan, keamanan, dan budaya sopan.

\section{F. Kesimpulan}

Aurat wanita muslimah di dalam keluarga tidak perlu adanya tabir ataupun jilbab. Keberlakuan batasan aurat muslimah di dalam surah al-Ahzab ayat 53 itu hanya ditujukan kepada Ummul Mu'minin. Pada ranah publik, dari sudut pandang Quraish bahwa berhijab itu ada tiga alasan, yang pertama adalah filosofis yang cenderung melawan kenikmatan nafsu manusiawi, kedua, keamanan karena dikhawatirkan bila wanita muslimah tidak berjilbab akan diganggu oleh laki-laki usil, dan ketiga alasan ekonomi.

Kontribusi Quraish terhadap batasan berhijab itu ada tiga yaitu, filosofis, keamanan, dan ekonomi. Itu semua sudah sesuai dengan maqashid syari'ah. Kritik terhadap Quraish, secara historis surah al-Ahzab ayat 59 untuk dapat membedakan antara wanita terhormat dengan budak. Akan tetapi dalam konteks masa kini perbudakan telah sirna dan jilbab pun hanya anjuran. Penulis mengutip pendapat ash-Shabuni, jika sebagian orang berkata demikian, dimungkinkan karena kurang fahamnya mereka tentang Islam dan al-Qur'an dan mungkin ada 
tujuan tertentu dari orang-orang yang berpandangan liberal. Kemudian pendapat Quraish yang mengatakan keluarga ulama atau aktivis muslimat Indonesia juga tidak sepenuhnya menutup aurat. Penulis mengutip pendapat Zain an Najah. yakni, tidaklah dibenarkan menerima hukum berdasarkan kelompok tertentu, yang perlu dijadikan rujukan adalah keluarga ataupun sahabat Nabi. Adapun diamnya ulama dengan keluarganya yang tidak menutup seluruh auratnya, dimungkinkan mereka sudah memerintahkan namun tetap membangkang, bukankah istri Nabi Nuh dan Nabi Luth juga membangkang.

\section{Daftar Pustaka}

Abu Bakr bin as-Saiyid Muhammad Syatha ad-Dimyathi. 1994. Hasyiah I'anah ath-Thalibin, Vol. 1, Damaskus: Dar al Fikr.

Ahmad Zahro. 2007. Fiqih Kontemporer. Surabaya: Unipdu Press.

Ardiansyah, 2014, Konsep Aurat Menurut Ulama Klasik Dan Kontemporer, Analytica Islamica, Vol.3, No.2.

Ash-Shofa, Burhan. 1998. Metode Penelitian Hukum. Jakarta: Rieneke Cipta.

Chamim Thohari. 2011. Kontruks Pemikiran Quraish Shihab Tentang Hukum Jilbab: Kajian Hermeneutika Kritis, Vol. 14 No. 1 Januari-Juni.

M. Quraish Shihab. 2002. Tafsir Al Misbah: Pesan, Kesan dan Keserasian Al Qur'an, Vol. 11. Jakarta: Lentera Hati.

M. Quraish Shihab. 2018. Jilbab Pakaian Wanita Muslimah: Pandangan Ulama Masa Lalu Dan Cendekiawan Kontemporer, Tangerang: PT. Lentera Hati.

2015. Pengantin Al Qur'an: 8 Nasihat Perkawinan Untuk Anak-Anakku. Tangerang: Lentera Hati.

Hasyim Asy'ari. 1995. Irsyadus Sari. Jombang: Pustaka Warisan Islam.

Imam al-Ghazali. 2009. Ihya' 'Ulumuddin, Vol. 4 terj. Moh. Zuhri, Semarang: CV. Asy Syifa.

Katni. Jilbab Dalam al-Qur'an Dan Al-Hadits Serta Aplikasinya Pada Pendidikan Islam Perspektif Teori Habitus Pierre Bourdieu. Al-Assasiya: Journal Of Basic Education Vol. 01 No. 01. ISSN: 2548-9992.

Milles, Matthew B. dan A. Michael Huberman. 2014. Analisis Data Kualitatif terj. Tjetjep Rohendi Rohidi. Jakarta: Universitas Indonesia.

Muhammad Sudirman Sesse. 2016. Aurat Wanita Dan Hukum Menutupnya Menurut Hukum Islam. Jurnal al-Maiyya Vol. 9 No.2, 327.

Muthmainnah Baso. 2015. Aurat Dan Busana. Jurnal al-Qadau Volume 2 Nomor 2,188 .

Muhammad Zaenuddin. Maqashid Syariah: Fungsi Dan Cara Mengetahuinya Kompasiana.com. 2018. Diakses pada 15 Agustus 2019.

Raudatul Jannah. 2018. Sudah Benarkah Kita Berhijab? , Bandung: Guepedia.

Rizem Aizid. 2018. Fiqh Keluarga Terlengkap, Yogyakarta: Laksana.

Rony Wijaya. 2019. Biografi Toko, http://bio.or.id/biografi-quraish-shihab/ di akses pada 4 Januari 2019. 
Segaf Hasan Baharun. 2012. Panduan Mudah Fiqih Muslimah. Bangil: Ponpes Dalwa.

Siti Mufidtaul Masruroh. 2018. Analisis Pasal 116 Ayat 5 Dan 6 KHI Tentang Alasan Perceraian Karena Cacat Badan Dan Perselisihan Perspektif Filsafat Hukum Islam. INAIFAS Jember.

Sugiyono. 2009. Metode Penelitian Kuantiatif, Kualitatif dan R\&D. Bandung: Alfabeta.

Ummu Aisyah Alawiyah, 2014, Jilbab Bukti Cintaku Padamu, Jombang: AshShofa.

Zizi Hefni, 2014, Pacaran After Merrid, Yogyakarta: de Teens. 